\title{
Kepemimpinan Kyai Dalam Memberdayakan Kewirausahaan Santri
}

\author{
Nur Hayana ${ }^{* 1}$ \& Wahidmurni ${ }^{* 2}$ \\ 1,2Universitas Islam Negeri Maulana Malik Ibrahim Malang \\ Email: 1'waodehayana769@gmail.com, 2wahidmurni@pips.uin-malang.ac.id
}

\begin{abstract}
Pondok Pesantren have contributed a lot in national development, including in terms of creating an independent workforce. One of them is to equip santri with entrepreneurial competencies. The aim of the study was to reveal the Kyai's strategy in empowering entrepreneurship of santri, Kyai's leadership style in empowering santri entrepreneurship, and the implications of Kyai's leadership in empowering santri entrepreneurship. A qualitative approach to the type of multisite case study was applied in the study. Data was collected by conducting in-depth interviews, participant observation and documentation studies. Data analysis uses data reduction, data presentation and conclusion drawing. The technique of checking the validity of research findings using triangulation of data sources and data collection techniques. The results showed that the strategies implemented by the Kyai in empowering santri entrepreneurship were carried out by giving an example of entrepreneurship, providing field learning, giving assignments in the pesantren business unit and providing motivation; the leadership style applied is a blend of democratic, transformative and charismatic leadership styles; the implication is that santri have a spirit of entrepreneurs.
\end{abstract}

Keywords. Kyai leadership; Santri entrepreneurship; Empowerment of santri.

Abstrak. Pondok pesantren telah banyak berkontribusi dalam pembangunan nasional, termasuk dalam hal penciptaan tenaga kerja yang mandiri. Salah satunya adalah membekali santri dengan kompetensi berwirausaha. Tujuan penelitian adalah untuk mengungkapkan strategi Kyai dalam memberdayakan kewirausahaan santri, gaya kepemimpinan Kyai dalam memberdayakan kewirausahaan santri, dan implikasi kepemimpinan Kyai dalam memberdayakan kewirausahaan santri. Pendekatan kualitatif dengan jenis penelitian studi kasus dengan rancangan multisitus diterapkan dalam penelitian. Data dikumpulkan dengan melakukan wawancara mendalam, observasi partisipan dan studi dokumentasi. Analisis data menggunakan reduksi data, penyajian data dan penarikan kesimpulan. Teknik pengecekan keabsahan temuan penelitian dengan menggunakan trianggulasi sumber data dan teknil pengumpulan data. Hasil penelitian menunjukkan bahwa strategi yang diterapkan Kyai dalam memberdayakan kewirausahaan santri dilakukan dengan memberikan keteladanan berwirausaha, memberikan pembelajaran lapangan, memberikan tugas di unit usaha pesantren dan memberikan motivasi; gaya kepemimpinan yang diterapkan adalah perpaduan dari gaya kepemimpinan demokratis, transformatif dan kharismatik; implikasinya santri memiliki jiwa enterpreneur dan enterpreneur berjiwa santri.

Kata kunci. Kepemimpinan kyai; Kewirausahan santri; Pemberdayaan santri.

Copyright (C JMPI: Jurnal Manajemen Pendidikan Islam. All Right Reserved.

This is an open access article under the CC BY-NC-ND license

(http://creativecommons.org/licenses/by-nc-nd/4.0/).

Vol. 4 No. 1, Juni Tahun 2019

J-MPI homepage: http://ejournal.uin-malang.ac.id/index.php/jmpi/index 


\section{A. PENDAHULUAN}

Keberhasilan suatu organisasi sangat ditentukan oleh figur yang visioner dan mampu membaca peluang yang ada dan merubahnya menjadi usaha yang menguntungkan baik bagi organisasi maupun masyarakat pada umumnya. Figur pemimpin yang dibutuhkan adalah figur yang dapat dijadikan panutan atau sebagai uswatun hasanah. Pemimpin yang diamanahkan untuk menjadikan umat manusia menjadi insan yang lebih baik dan berada pada jalan yang sesuai dengan perintah Allah adalah bukan suatu mudah. Lebih-lebih dalam kondisi ketidakpastian lingkungan saat ini, dimana perubahan begitu cepat terjadi dan dibutuhkan pemimpin yang memiliki kompetensi tinggi. Abbas \& Asghar (2010) menyatakan bahwa inovasi merupakan kunci sukses suatu organisasi dalam jangka panjang, untuk itu perubahan organisasi yang kompleks dapat ditangani oleh pemimpin yang memiliki kompetensi "visi" dan "pendekatan inovatif" bersama dengan karakteristik lainnya.

Dalam kehidupan pesantren, Kyai memiliki peran yang sentral, sebab di tangan beliaulah roda kehidupan pesantren ditentukan. Hal ini juga termasuk dibutuhkan kompetensi Kyai dalam menghadapi perubahan yang terjadi. Kyai yang memiliki jiwa kewirausahaan selalu berpikir visioner untuk melakukan segala antisipasi pada tuntutan jaman yang berubah. Kyai yang demikian tidak melayani dirinya saja akan tetapi juga melayani umat, melayani santri dan memberikan semua apa yang dimiliki demi kemajuan pesantren dan santri serta masyarakat.

Dewasa ini, juga telah berkembang pondok pesantren, di samping memberikan pendididikan sebagaimana pondok pesantren pada umumnya juga memberikan bekal kewirausahaan pada para santrinya. Pemberian bekal kewirausahaan ini bertujuan agar alumninya dapat berkontribusi dalam penciptaan lapangan kerja di samping memiliki kemampuan bidang keagamaan sebagai sarana dakwah. Untuk itu pondok pesantren dikelola dengan menggunakan prinsip manajemen bisnis. Hal ini senada dengan kesimpulan penelitian Zuliani et al. (2018) bahwa manajemen pesantren dalam entrepreneurship berarti bahwa pemimpin podok pesantren memberdayakan santri dan alumninya untuk mengembangkan unit usaha melalui sub bagian-bagian untuk mengembangkan unit usaha baru. Hal ini telah dicontohkan oleh Pondok pesantren Riyadlul Jannah Pacet Mojokerto dan pondok pesantren Sidogiri Pasuruan, kedua pondok pesantren ini merupakan contoh pondok pesantren yang berhasil mengembangkan kewirausahaan.

Sebagaimana diungkapkan Ketua Batartama pondok pesantren Sidogiri Pasuruan bahwa Kyai dalam memberdayakan kewirausahaan santri dan santri yang berwirausaha, adalah dengan memberikan penekanan pada fondasi utamanya yakni Tauhid dan Syariah bukan diajarkan teori dagang dan praktek jual beli saja. Dengan ditanamkan bekal tauhid dan syariah ini akan muncul kemandirian, dan dari kemandirian akan muncul ketaqwaan dan kesungguhan dalam berwirausaha. Sebagaimana di dalam Tauhid Allah adalah Al-Mughnii dan Al-Badiiy. Dengan demikian, dalam diri santri tidak lepas dari yang namanya tauhid dan syariat. Aqidah pun diajarkan tidak sepotong-potong, dan dalam syariat ada ibadah dan muamalah, diantara Muamalah itu ada wirausaha.

Demikian halnya di pondok pesantren Riyadlul Jannah di bawah pimpinan KH. Mahfudz Syaubari yang memiliki banyak perusahaan. Kyai dalam kepemimpinannya itu dimulai dari pemenuhan kebutuhan santri itu sendiri, sehingga ketika santri sudah dapat memenuhi kebutuhannya sendiri, maka untuk memulai sesuatu usaha santri akan

Vol. 4 No. 1, Juni 2019

J-MPI homepage: http://ejournal.uin-malang.ac.id/index.php/jmpi/index 
menjadi lebih mudah, hal ini sebagaimana dinyatakan oleh putri Kyai. Berangkat dari kemajuan dan perkembangan kewirausahaan yang ada di dua pondok pesantren ini, perlu diungkap tentang strategi Kyai dalam memberdayakan kewirausahaan santri, gaya kepemimpinan Kyai dalam memberdayakan kewirausahaan santri, dan implikasi kepemimpinan Kyai dalam memberdayakan kewirausahaan santri.

\section{B. METODE}

Penelitian berusaha mengungkap strategi Kyai dalam memberdayakan santri untuk berwirausaha, untuk itu peneliti berupaya mengungkap apa adanya peristiwaperistiwa yang diamati, mengkaji dokumen pondok pesantren, serta apa yang diungkapkan Kyai, pengasuh, santri atau stakeholder pesantren tentang apa yang mereka alami dalam Pondok Pesantren dalam mengembangkan kewirausahaan santri. Untuk mencapai tujuan ini digunakan pendekatan penelitian kualitatif dengan jenis penelitian studi kasus.

Adapun rancangan penelitian yang diterapkan adalah rancangan multisitus, sebab terdapat banyak persamaan yang terjadi di dua situs penelitian di pondok pesantren Riyadlul Jannah Pacet Mojokerto dan pondok pesantren Sidogiri Pasuruan. Sumber data dalam penelitian ini adalah ketua Batartama pondok pesantren Sidogiri Pasuruan dan beberapa orang pengasuh. Putra-putri Kyai dan beberapa orang pengasuh pondok pesantren Riyadlul Jannah Pacet. Data yang dikumpulkan berupa ungkapan, pendapat, persepsi mereka tentang segala hal yang berkaitan dengan kepemimpinan Kyai dalam memberdayakan santri berwirausaha. Sumber data utama dalam penelitian kualitatif adalah kata-kata dan tindakan selebihnya adalah data tambahan seperti dokumen dan observasi. Analisis data dilakukan dengan cara melakukan reduksi data, menyajikan data, dan melakukan penarikan kesimpulan. Untuk menjamin keabsahan temuan penelitian digunakan triangulasi sumber data dan teknik pengumpulan data.

\section{HASIL DAN PEMBAHASAN}

\section{Strategi Kepemimpinan Kyai dalam Memberdayakan Kewirausahaan Santri}

Hasil penelitian menunjukan strategi kepemimpinan Kyai dalam memberdayakan kewirausahaan santri adalah dengan pemberian keteladanan diantaranya dengan memberikan arahan dan bimbingan kepada santri dan santriwati. Ini mengindikasikan pentingnya konsep keteladanan dalam pendidikan, sebab keteladanan dapat berpengaruh terhadap proses pendidikan khususnya dalam membentuk aspek moral, spiritual dan etos sosial santri. Hal ini mendukung temuan Huda (2016) bahwa kunci utama kesuksesan alumni Universitas Islam Negeri (UIN Walisongo) Semarang yang berkarir sebagai pengusaha adalah memiliki etos kerja yang tinggi, dan semangat kerja yang didorong oleh motif religi dan sosial.

Dalam pandangan Islam keteladanan merupakan metode pendidikan yang terbaik dan yang paling membekas (Muallifah, 2009). Keteladanan sangat penting untuk ditanamkan dan diaplikasikan oleh seorang pemimpin dalam kehidupannya. Dalam lingkup pesantren Kyai yang menjadi panutan dan cerminan utama santri dan santriwati dalam memberikan keteladanan. Hal ini selaras yang diungkapkan oleh Ulwan (dalam Rachman dan Hijran, 2017) bahwa keteladanan merupakan metode influentif untuk membentuk dan mempersiapkan moral, spritual dan kecakapan sosial peserta didik yang keberhasilannya paling meyakinkan dalam pendidikan.

Vol. 4 No. 1, Juni Tahun 2019

J-MPI homepage: http://ejournal.uin-malang.ac.id/index.php/jmpi/index 
Setiap pelajaran dan prinsip kehidupan yang diajarkan menuntut adanya keteladanan dari orang yang mengajarkannya. Ajaran akan lebih bermakna jika disampaikan dengan keteladanan. Keteladanan adalah ruh yang membuat setiap yang disampaikan menjadi hidup, bermakna dan memiliki manfaat. Jika masih ada keteladanan maka masih ada harapan pendidikan yang membuat hasil yang baik (Jalil, 2018).Ini sejalan yang dilakukan oleh Kyai di dua pondok pesantren dalam memberdayakan kewirausahaan santri merupakan keteladanan yang sangat tepat dan baik dengan memberikan keteladanan santri dan santriwati mengikuti keteladanan seperti Kyai yang langsung terjun kelapangan dalam memberikan keteladanan atau uswah kepada santri dan santriwati. Temuan ini mendukung temuan penelitian yang menyatakan bahwa keteladanan lebih efektif digunakan dalam pembelajaran. Kesimpulan Mubarok (dalam Jalil, 2018) menyatakan bahwa 83 persen anak dipengaruhi oleh apa yang dilihatnya, 11 persen dipengaruhi oleh apa yang didengarnya, dan 6 persen dipengaruhi oleh rangsangan/stimulus. Praktek lapangannya adalah Kyai dalam pondok pesantren memberikan contoh seperti terjun ke lapangan bekerja secara langsung bukan hanya sekedar berbicara saja dalam majelis.

Di Negara-negara Barat prasyarat keteladanan merupakan faktor krusial. Secara khusus perusahaan-perusahaan kelas dunia yang sukses, bertahan dan terus berkembang dan kemudian menjadi acuan bagi yang lainnya, menemukan bahwa perusahaan-perusahaan tersebut itu memiliki satu kesamaan prinsip yakni pemimpin yang memiliki keteladanan. Dimana keteladanan memerlukan toleransi, kerendahan hati, dan kesabaran. Pemimpin adalah pamong bukan pangreh. Hal ini sebagimana pernyataan dari Ki Hajar Dewantara senantiasa mengajarkan bahwa pemimpin harus memberi keteladanan (Karim, 2008).

Temuan juga mengindikasikan bahwa seorang pemimpin harus memberikan keteladanan. Jika keteladanan tidak melekat pada seorang pemimpin, darimana bawahan atau santri mencontoh, mengaplikasikannya dalam kehidupan. Hal ini menjelaskan keteladanan merupakan da'wah bil hal. Apa yang dilakukan Kyai di dua pondok pesantren menunjukkan bukti kewirausahaan santri yang berkembang dan maju sehingga dikenal oleh banyak orang. Dalam hal ini keteladanan yang diberikan Kyai adalah dengan pembelajaran lapangan atau langsung terjun ke lapangan untuk memberdayakan kewirausahaan santri.

Dalam hal ini, sebagaimana cara terampuh untuk grooming people adalah dengan langsung terjun ke lapangan, berinteraksi langsung dengan anak buah dalam memecahkan persoalan-persoalan yang dihadapi organisasi. Dengan terjun di lapangan si pemimpin akan bisa menunjukkan secara on the spot nilai-nilai dan perilaku seperti apa yang harus dipraktikkan oleh anak buah. Pemimpin sekaligus juga dapat mengasah kemampuan (knowledge, skill, experience) anak buah sesuai dengan kebutuhan dan tujuan organisasi (Fahlevi, 2018).

Temuan lainnya adalah adanya pembelajaran di lapangan secara langsung, untuk melihat dan berintraksi dengan santri dan santriwati sehingga Kyai dapat langsung memberikan ilmu, kemampuan dan pengalaman selama di lapangan dalam melakukan kegiatan kewirausahaan di pesantren. Di samping itu, juga diberikan tugas-tugas kepada santri dan santriwati sebagai wadah latihan dan pengembangan diri dalam bersikap untuk bertanggung jawab. Pemberian tugas-tugas ini yakni dengan di tugaskan menjaga toko atau unit-unit usaha yang dimiliki oleh pesantren. Keadaan ini menurut Sagala

Vol. 4 No. 1, Juni 2019

J-MPI homepage: http://ejournal.uin-malang.ac.id/index.php/jmpi/index 
(2018) dinyatakan bahwa pemimpin memberikan kedudukan, memberikan tugas, memberi tanggung jawab, memberikan kesempatan mewakili, mengajak, membujuk, meminta saran, meminta pendapat dan pertimbangan, memberikan kesempatan berperan. Metode pembelajaran dengan memberikan tugas langsung di lapangan telah terbukti menghasilkan lulusan yang berhasil hidup mandiri dengan cara berwirausaha. Temuan ini mendukung temuan penelitian Panfilova et al. (2019) tentang pelaksanaan pendidikan kewirausahaan berbasis model pembelajaran pada proyek nyata menunjukkan bahwa partisipasi mahasiswa meningkatkan ketrampilan profesional sebesar 6\% - 10\%, sekitar 60\% mahasiswa merasa meningkatkan minatnya, 73\% mahasiswa merasakan tertarik, dan temuan Wahidmurni et al. (2019) yang menunjukkan tugas praktik bisnis berwirausaha yang diterapkan oleh perguruan tinggi mampu mendorong lahirnya founder startup yang berhasil.

\section{Gaya Kepemimpinan Kyai dalam Memberdayakan Kewirausahaan Santri}

Temuan penelitian menunjukkangaya kepemimpinan Kyai dalam memberdayakan kewirausahaan santri yakni gaya kepemimpinan demokratis, Kyai sebagai figur dalam pondok pesantren yang memegang kendali utama demi kelangsungan maju dan berkembangnya pondok pesantren. Kyai dalam pondok pesantren memeiliki prean sentral. Kyai diposisikan sebagai guru spiritual baik santri dan masyarakat sekitarnya. Pada kedua situs penelitian, Kyai banyak membawa perubahan dan kemajuan untuk pesantren baik dari segi keilmuan yang dimiliki maupun dari segi kewirausahaan yang dimiliki pesantren dalam memberdayakan santrisantrinya.

Dalam praktiknya gaya kepemimpinan yang diterapkan oleh seorang manager suatu organisasi (bisnis dan non bisnis) dapat saja berubah seiring dengan perubahan dinamika yang berkembang dalam diri para karyawan. Sebagaimana diketahui, para karyawan merupakan salah satu komponen dalam dalam lingkungan organisasi yang dinamis dan bukan statis. Para karyawan yang awalnya tidak memiliki kemampuan kerja apa-apa masih memerlukan bimbingan kerja, tetapi karena ketekunan dan keuletan mereka bekerja, pada suatu saat tertentu mereka telah memiliki kemampuan yang baik tentang bagaimana menyelesaikan tugas dan pekerjaannya dengan baik (Purwanto, 2006).

Oleh karena itu gaya kepemimpinan demokratis untuk mencapai kata sepakat itu ialah metode diskusi. Seperti kita ketahui bersama bahwa diskusi adalah suatu bentuk pertukaran pikiran yang dilaksankan secara teratur. Adapun bentuk pertukaran pikiran adalah agarsemua anggota terlibat dan memiliki kesempatan untuk menyampaikan sumbangsih pikiran masing-masing (Mangunhardjana, 1976).

Berkaitan dengan pemberdayaan kewirausahaan santri ini yakni dimana Kyai ikut melibatkan santri dalam menyampaikan gagasan, ide dan kritikan yang berkaitan dengan kewirausahaan santri sehingga disini gaya kepemimpinan Kyai dalam memberdayakan kewiraushaan santri secara kepemimpinan demokratis kyai ikut melibatkan santri dalam musyawarah bila ada kritikan dan saran yang bersifat membangun.

Di sisi lain temuan juga menunjukkan bahwa kepemimpinan transformatif dan karismatik juga diterapkan oleh Kyai. Sebagaimana temuan Ahmad (2016) kepemimpinan transformatif adalah pemimpin yang peduli, menghargai keterampilan-

Vol. 4 No. 1, Juni Tahun 2019

J-MPI homepage: http://ejournal.uin-malang.ac.id/index.php/jmpi/index 
keterampilan dan kemampuan khusus individu-individu lain. Dia menciptakan berbagai peluang dan selalu memberikan peluang dan kesempatan terhadap anggotanya. Hal ini sebagaiman dinyatakan Afandi (2013) bahwa dalam menerapkan kepemimpinan transformatif seorang Kyai di pesantren adalah tidak hanya mengandalkan kharisma personal, tetapi ia harus mencoba untuk memberdayakan staffnya serta melaksanakan fungsi-fungsi kepemimpinanya. Seorang pemimpin di pesantren harus mampu memberikan peluang seluas-luasnya kepada santri untuk berpartisipasi dalam program pesantren.

Menurut Michael Amstrong kepemimpinan transformatif sebagai kepemimpinan yang memberdayakan pengikutnya dan mendorong mereka untuk melakukan sesuatu yang melebihi harapan awal mereka. Pemimpin memotivasi pengikut mereka untuk tampil ditingkat lebih tinggi, untuk mengarahkan upaya pengikut mereka ke arah yang lebih besar, dan menunjukkan komitmen yang lebih (Umiarso, 2018).

Adapun kepemimpinan kharismatik Kyai dalam pondok pesantren menjadikan Kyai sebagai panutan dan memiliki banyak pengikut. Dalam hal ini memberdayakan kewirausahaan santri di pondok pesantren di dua situs penelitian, daya tarik Kyai sangat luar biasa sehingga dengan mudah mengayomi dan mengajak santri-santriwati untuk mengikuti apa yang menjadi perintah dari Kyai. Imam (2015) menyatakan bahwa kepemimpinan kharismatik Kyai memiliki kekuatan energi, daya tarik dan pembawaan yang luar biasa untuk mempengaruhi orang lain, sehingga ia mempunyai pengikut yang sangat besar jumlahnya dan pengawal-pengawal yang bisa dipercaya. Kepemimpinan kharismatik ini dianggap memiliki kekuatan ghaib (supernatural power) dan kemampuankemampuan superhuman yang diperolehnya sebagai karunia Yang Maha Kuasa. Kepemimpinan kharismatik memiliki inspirasi, keberanian dan keyakinan teguh pada pendirian sendiri. Totalitas kepemimpinan kharismatik memancarkan pengaruh dan daya tarik yang sangat besar. Pemimpin kharismatik ini sangat cocok sebagai publik figur dimana dengan kharisma yang dimilikinya dapat mempengaruhi orang-orang disekitarnya.

\section{Implikasi Kepemimpinan Kyai dalam Memberdayakan Kewirausahaan Santri}

Implikasi kepemimpinan Kyai dalam memberdayakan kewirausahaan santri mampu menciptakan santri yang berjiwa enterpreneuership. Jiwa enterpereneur dapat mengembangkan bakat atau ilmu yang telah dimiliki selama dipesantren untuk diaplikasikan dalam kehidupan bermasyarakat, sehingga santri-santri ini dapat berguna untuk orang lain dan dirinya sendiri. Karim (2008) menyatakan bahwa jiwa enterpreneur adalah jiwa dimana individu atau kelompok dalam organisasi dapat mengolah sumbersumber yang berupa kesempatan, tantangan menjadi hasil.

Jiwa entrepreneurship memotivasi seseorang untuk berpikir ektra dan kreatif agar bisa lebih sejahtera. Saat ini banyak kasus korupsi karena semua orang ingin memiliki uang lebih banyak, ingin sejahtera dalam takaran yang mereka inginkan. Lain halnya dengan mereka yang berjiwa entrepreneurship akan berjuang dengan kreatif dan penuh kerja keras dalam meraih apa yang dicita-citakan termasuk mejadi sejahtera. Entrepreneurship akan mengantar seseorang menjadi manusia penuh daya yang bukan hanya bisa menolong dirinya sendiri tapi juga menolong orang lain.

Seorang karyawan yang memiliki jiwa entrepreneurship senantiasa tidak mau diam, atau sekedar hanya mengekor orang lain. Dia selalu kreatif, bisa menjadi pelopor 
di komunitas pekerjaan, selalu menciptakan ide-ide baru dan menjadikan hidup menjadi tidak monoton dan membosankan. Jiwa enterpeneurship bukan semata mata uang atau bisnis yang berorientasi semata pada materi melainkan kepribadian yang senantiasa produktif dengan inovasinya untuk menciptakan nilai tambah bagi dirinya dan orang lain (Iskandar, 2013).

Kewirausahaan santri diharapkan menghasilkan santri yang tumbuh menjadi pegusaha tangguh dimasa depan. Menjadi apapun dimasa depan baik itu pejabat, insinyur milikilah yang berjiwa santri. Khozin (2018) menyatakan berjiwa santri adalah selalu mengedepankan ibadah, mengedepankan akhlak dan perilaku yang baik, sehinggga dengan terciptanya pengusaha yang berjiwa santri diharapkan kedepannya nanti sesukses apapun dan dimanapun hal yang paling utama yakni ibadah, ibadah dan ibadah. Sebab, jika pengusaha berjiwa santri mereka akan selalu hidup dalam kesederhanan selalu hidup dalam ibadah selalu istiqomah dalam menjalankan usaha dengan tidak melupakan jiwa santri yang telah melekat pada dirinya.

\section{KESIMPULAN}

Strategi yang diterapkan Kyai dalam memberdayakan kewirausahaan santri adalah dengan meletakkan fondasi utama Tauhid dan Syariah, selanjutnya dilakukan dengan memberikan keteladanan dalam berwirausaha yakni adanya usaha yang dijalankan oleh Kyai dalam mengembangkan pesantrennya. Melalui usaha ini para santri dapat dimotivasi dan mempraktikan secara langsung dalam kehidupan di masyarakat, yakni terlibat dalam mengelola dan mengembangkan unit usaha pesantren. Untuk menjamin keberhasilan wirausaha santri diterapkan kombinasi atau perpaduan beberapa gaya kepemimpinan yakni dari gaya kepemimpinan demokratis, transformatif dan kharismatik. Gaya kepemimpinan ini dalam pelaksanaan saling menguatkan satu dengan yang lainnya. Ini menunjukkan fleksibelitas gaya kepemimpinan untuk menggerakan santri agar termotivasi dalam berwirausaha. Implikasi kepemimpinan Kyai dalam memberdayakan kewirausahaan santri adalah para santri memiliki jiwa enterpreneur dan enterpreneur berjiwa santri. Setidaknya santri memiliki keinginan menjadi pengusaha, atau setidaknya jika menjadi bukan pengusaha ia telah memiliki jiwa entrepreneur yang mampu berpikir kreatif dan mampu bekerja lebih baik.

\section{REFERENSI}

Abbas, W. \& Asghar, I. (2010). The role of leadership in organizational change: relating the successful organizational change to visionary and innovative leadership. Master's Thesis in Industrial Engineering and Management, Faculty of Engineering and Sustainable Development, University of Gavle.

Afandi, R. (2013). Efektifitas Kepemimpinan Transformasional Pesantren Bagi Peningkatan Mutu Lembaga Pendidikan Islam. Jurnal Kependidikan, 1 (1), 99-121

Ahmad, M. (2016). Membangun Kemandirian Ekonomi Santri Melalui Kepemimpinan Transformasional Kiai: Studi Kasus Pondok Pesantren Putra Miftahul Mubtadiin di Kecamatan Tanjunganom Kabupaten Nganjuk. Disertasi UIN Sunan Ampel Surabaya.

Fahlevi, D. (2018). Quantum Leadhership The 5 Tahun Level Of Execution. Jakarta: PT Gramedia Pustaka Utama.

Huda, C. (2016). Etos Kerja Pengusaha Muslim (Studi Kasus pada Pengusaha Muslim Alumni UIN Walisongo Semarang). Economica, VII (2), 79-107.

Vol. 4 No. 1, Juni Tahun 2019

J-MPI homepage: http://ejournal.uin-malang.ac.id/index.php/jmpi/index 
Imam, M. (2015). Book of Mentor 1: Leader University Step By Step Leader. Kim Ara Holding Group.

Iskandar, A. M. (2013). Action for One Family Enterpreneur. Jakarta: PT Gramedia Pustaka. Jalil, J. 2018. Pendidikan Karakter Implementasi oleh Guru, Kurikulum dan Sumber Daya Pendidikan. Jakarta: CV Jejak.

Karim, S. (2008). Awang Faroek Ishak Di Mata Para Sahabat Edisi 2. Jakarta: Indomedia.

Khozin, M. (2018). Santri Milenial. Jakarta: Buana Ilmu Popular.

Mangunhardjana, A. S. (1976). Kepemimpinan. Yogyakarta: Kanisius.

Muallifah. (2009). Psycho Islamic Smart Parenting. Jakarta: Diva Press.

Panfilova, E. E., Demkina, O. V., Galichkina, M. A., Istomina, A. I., Latysheva, V. V. \& Teymurova, V. E. (2019). Learning models based on a real project in entrepreneurial education. Journal of Entrepreneurship Education, 22 (2), 1528-2651-22-2-324.

Purwanto, D. (2006). Komunikasi Bisnis Edisi Tiga. Jakarta: Erlangga.

Rachman, F. \& Hijran, M. (2017). Kajian Keteladanan dalam Memperkuat Pendidikan Indonesia, The 5th Urecol Proceeding, 18 February, UAD, Yogyakarta, 998 - 1003.

Sagala, S. (2018). Pendekatan \& Model Kepemimpinan. Jakarta: Kencana.

Umiarso. (2018). Kepemimpinan Transformasional Profetik Kajian Paradigmatic Ontos Integralistik di Lembaga Pendidikan Islam. Jakarta: Divisi Kencana.

Wahidmurni. Nur, A. M., Abdussakir. Mulyadi \& Baharuddin. (2019). Curriculum development design of entrepreneurship education: A case study on Indonesian higher education producing most startup founder. Journal of Entrepreneurship Education, 22 (3), 1528-2651-22-3-374.

Zuliani. Zulfahmi. \& Ilham. (2018). Kontribusi manajemen sumber daya manusia (SDM) terhadap pemberdayaan enterpreneurship santri di pesantren modern Tgk. Chiek Oemar Diyan Indrapuri Aceh Besar. Jurnal Manajemen dan Inovasi, 9 (2), 33 - 43. 